SECTION 1. Theoretical research in mathematics.

Umarov Aman Tulepbergenovich candidate of pedagogical Sciences, senior lecturer of "Information science and mathematics" Kazakhstan Institute of engineering and pedagogical University of friendship of peoples, Kazakhstan

\title{
THE USE OF THE PRINCIPLE OF HISTORICISM IN MATH CLASS IN HIGH SCHOOL
}

Implementing the reform of secondary and professional education, the government should focus on educational role, formation of skills of independent work of students, increase the responsibility of teachers for the quality and effectiveness of the educational process. The objective implications of new social trends emerging in recent years, the acceleration of scientific and technical progress, increasing the creative nature of work and the strengthening of human factors strongly demands search for new forms and methods of organization of educational activity.

Keywords: the lesson of mathematics, school, the principle of historicism.

\section{ИСПОЛЬЗОВАНИЯ ПРИНЦИПА ИСТОРИЗМА НА УРОКАХ МАТЕМАТИКИ В СРЕДНЕЙ ШКОЛЕ}

$\begin{array}{rcrlr}\text { Претворяя в жсизнь реформу общеобразовательной } & \text { в } \\ \text { профессиональной } & \text { школь, }\end{array}$ воспитательную роль, формирование умений и навыков самостоятельной работы учащихся, повысить ответственность учителя за качество и эффективность учебно-воспитательного процесса. Объективные последствия новых сощиильных тенденций, наметивщихся за последние годы, ускорение научно-технического прогресса, повышения творческого характера труда, усиление человеческого фактора настоятельно требует поиска новых форм и методов организации учебной деятельности.

Ключевые слова: урок, математика, школа, принцип историзма.

Одной из наиболее существенных причин этого является то обстоятельство, что при обосновании принципа историзма слабо учитывалась его взаимосвязь с фундаментальными положениями педагогики, в первую очередь с требованием формирования мировоззрения школьников в процессе их разностороннего духовного развития. 
Неразрывная связь и единствозадач формирования диалектикоматериалистического мировоззрения учащихся, задач всестороннего воспитания, обучения и развития - вот что позволяет дать научное обоснованиевыводу о желательности, целесообразности и необходимости использования историко-математического материала при изучении современного курса математики.

Возможности применения принципа историзма в школах, несомненно, должны опираться на краеведческий материал. В этом смысле школы республик Средней Азии располагают богатейшими возможностями. Поэтому в нашем исследовании основной акцент делается на наследие ученых-математиков средневековой Средней Азии и Ближнего Востока. Именно в те времена ученые, собрав в себя мысли своих предшественников античного периода, придали математическим исследованиям качественно новое направление, обогатив науку открытиями первостепенной важности..

Среднеазиатские и Ближневосточные математики средних веков посвещали свои труды совершенствованию методов счета, открыли десятичные дроби. Ал-Хорезми считается отцом алгебры, ал-Каши тригонометрии. Современные исследователи истории науки находят все новые и новые математические трактаты, открывают новые имена. Одно из открытий - сочинение ученого X века ал- Уклидиси «Книга начал об индийской арифметике», где встречается наиболее ранняя из известных попыток применения десятичных дробей.

Как показала практика обучения, ознакомление учащихся с историей науки дает импульс их нравственному совершенствованию, воспитание в духе патриотизма и интернационализма. Пример жизни великих мыслителей прошлого, ознакомление с их научным вкладом и нравственным убеждениями оказывает сильное влияние на процессы самосовершенствования и самовоспитания школьников.

Изучая педагогически опыт многих учителей математики, мы пришли к выводу, что в процессе обучения они мало используют богатые возможности программного материала школьного курса математики в воспитательных целях. При работе учителей с существующими учебниками математики, элементы истории математики использовались в преподавании редко, бессистемно. Лишь в последнее время стали появляется исследования восполняющие пробелы.

Между тем, объем материалов по истории математики, в период проведения реформы школы, при переходе к новым, более доступным учебникам, возрастает от класса к классу. Бесспорную теоретическую и практическую ценность имеет при этом определение места, роли, формы подачи элементов истории математики, включаемых в процесс изучения школьного курса, и их влияние на формирование личности школьника, особенно в условиях 12-летней реформированной школы. В свете выше 
изложенного наша попытка обоснования принципов историзма в процесс обучения математики в школе и изучения возможностей включения историко-математических материалов в учебно-воспитательный, является весьма актуальной.

\section{Әдебиеттер}

1. Умаров А.Т.Педагогические основы использования принципа историзма на уроках математики в средней школе.Автореферат диссертации на соискание ученой степени кандидата педагогических наук. Ташкент.1989. 2. Умаров А.Т. Тиллашев Х.Х. «Усиление мировоззренческой направленности в обучении математике. Ташкент. Издательство Узбекистан, 1986. 